\title{
THERAPEUTIC TRIALS IN ACUTE GOUTY ARTHRITIS
}

\author{
MELVIN H. LEVIN, STANLEY MARCUS, DAVID STRANGE, AND ROBERT L. SWEZEY \\ From the Veterans Administration Center, Los Angeles, Calif., and the Department of Medicine, School of \\ Medicine, University of California Medical Center, Los Angeles, California
}

(RECEIVED FOR PUBLICATION JULY 30, 1956)

Colchicine remains the agent of choice in the treatment of acute gouty arthritis. In recent years valuable additions to the therapeutic armamentarium in this disease include $\mathrm{ACTH}$, cortisone, hydrocortisone acetate, prednisone, and Butazolidin (Wolfson, Hunt, Cohn, Robinson, and Duff, 1950; Gutman and Yü, 1950, 1952; Freyberg, 1955; Hartung, 1955; Steinbrocker, Neustadt, and Ehrlich, 1954). All of these are effective systemically, and in addition hydrocortisone acetate appears beneficial when administered intra-articularly.

The mechanism of action of colchicine (used either orally or intravenously) has been an enigma for centuries, and it was hoped that information on the modus operandi of these other potent anti-gout agents might shed some light upon it. Unfortunately, in spite of the mass of literature that has accumulated on the use of these drugs in the past 5 years, the mechanism by which they exert their effect has not been revealed. We are left then with the well-known non-specific "anti-phlogistic" explaation-a concept in need of further clarification.

An understanding of the mechanism by which therapeutic agents exert their effect represents a possible clue to the solution of the factors responsible for acute gouty arthritis. This is particularly true for the time-tested colchicine, since of all the drugs mentioned only colchicine is specific for the acute arthritis of gout alone.

Several hints relating to the possible effects of antigout agents have been suggested by recent work. One of these is the fact that colchicine given in therapeutic doses orally during studies of metabolic balance induces temporary $\mathrm{Na}, \mathrm{Cl}$, and $\mathrm{H}_{2} \mathrm{O}$ retention (Levin, Rivo, and Bassett, 1953). This, coupled with the salt-retaining effects of ACTH, cortisone, hydrocortisone, and also Butazolidin, suggests that agents capable of inducing $\mathrm{Na}$ and $\mathrm{Cl}$ retention but devoid of an "anti-inflammatory" effect might profitably be explored in the treatment of acute gouty arthritis. For these reasons desoxycorticosterone was used in this study.

Another clue was the finding that certain steroids exert their "anti-phlogistic" effect when given locally (Hollander, 1953, 1955; Stevenson, Zuckner, and Freyberg, 1952). This suggested the possibility that colchicine exerted a purely local effect upon the inflammation of gouty arthritis. Before using colchicine locally, studies were done on rabbits (Levin, 1956). It was found that the colchicine solution commercially available for intravenous use, when administered intra-articularly into rabbit knee-joints in doses of 0.25 to $1.0 \mathrm{ml}$., produced no local synovial inflammatory response as determined by microscopic examination after 24 and 48 hours, isotonic saline being used as a control in the contralateral knee. It was, therefore, decided to use this agent intra-articularly in gouty joints.

The idea has often been put forward that acute gouty arthritis represents an allergic response of the articular and peri-articular structure to allergens so far unknown (Ferrannini and De Pergola, 1950; Violle, 1947; Harkavy, 1949). The rapidity of onset and the cardinal signs of inflammation plus the occasional history of what may represent ingestant allergy in certain gouty individuals suggest that an allergic reaction may be involved in this disease. The effect of steroids upon allergic ailments also seems to support this view. Accordingly, the effects of large doses of an anti-histamine, diphenhydramine hydrochloride*, were studied in this disease.

Finally, other drugs closely related to colchicine structurally were studied from the point of view that certain differences in chemical composition may produce differences in physiological and pharmacological response. Colcemide (Demecolcine $\dagger$ ), a

\footnotetext{
* Benadryl, Parke-Davis.
+ "Demecolcine" was generously supplied by Ciba Pharmaceutical Products, Inc.
} 
new alkaloid obtained from the bulbs of Colchicum autumnale, differs from colchicine only in that the acetyl group of the latter is replaced by a methyl group. Since this agent has been used rather extensively on patients with tumours and lymphomata and is relatively safe in small doses (Moeschlin, Meyer, and Lichtmen, 1953; Leonard and Wilkinson, 1955; Bock and Gross, 1953), it was decided to test it in gouty patients. Complete blood counts were performed on this group of gouty subjects at least twice weekly.

\section{Material and Methods}

As a result of the above speculations, four therapeutic programmes were established.

(1) Desoxycorticosterone intramuscularly;

(2) An intravenous solution of colchicine intraarticularly;

(3) Benadryl intravenously and orally;

(4) Colcemide ("Demecolcine") intravenously and orally.

All the patients so treated were individuals with known gout established by the usual clinical, laboratory, and $x$-ray criteria. Only patients who had previously responded to full oral doses of colchicine were used and the response of all agents was compared with that of previous courses of colchicine. Particulars of the dosage, route of administration, site of attack, response, and sideeffects are given in the Table (opposite).

\section{Results}

DOCA.- None of the three gouty episodes treated with DOCA responded well. Patient 1, though responding moderately well subjectively, demonstrated slow resolution of the inflammatory process; comparing this to the natural course of his attacks, he felt that the resolution of the attack was acceleated. In no other patient was there any evidence that DOCA altered the illness either favourably or unfavourably.

Local Colchicine.--In all four patients treated with the intravenous solution of colchicine intraarticularly, the disease progressed during treatment. In no instance was there any favourable influence upon the gouty attack and other agents were required to terminate the episode. Three of the four, particularly Patient 4 , seemed to become definitely worse; within several hours after the injection rapid exacerbation of the inflammatory process out of proportion to the usual progress of the attack was observed. All responded well to other agents and no instance of residual joint damage was noted.
Benadryl.-None of the three cases receiving Benadryl showed any improvement. No evidence of undesirable side-effects was seen.

Colcemide.-All of the five patients treated with colcemide ("Demecolcine") showed clinical improvement within 48 hours, the response being comparable to that expected with therapeutic doses of colchicine. In Patients 12 and 15 the initial response was followed by a re-exacerbation of the process about 2 days after therapy was begun.

Side-effects were not observed, though in Patient 15 diarrhoea, which had been induced by colchicine, continued throughout the period of colcemide treatment.

\section{Discussion}

It is obvious that our experience with the use of DOCA, local colchicine, and Benadryl in acute gouty arthritis, was unrewarding. No evidence was found of any ameliorating effect upon the disease, in the dosage and methods used. Local colchicine appeared to aggravate the severity of the attack. Since this material was innocuous in rabbits, the inference is that species differences, changes inherent in gouty patients, or other ung known factors were responsible for this phenomenono The evidence would favour the idea that the mechanism of action of colchicine is not a local one?

In addition, although this is certainly not conclusive, the failure of Benadryl to affect the disease seems to show that allergy per se, in the usual clinical sense with histamine release, does not play a central role in acute gouty arthritis.

The failure of DOCA to help these patients, who later responded to other known anti-gout agents, most of which are salt-retaining, suggests that sodium and chloride retention per se is not a crucial factor in the modus operandi of the specific anti-gout effect of colchicine and other agents.

The results of the use of colcemide (Demecolcine) are interesting, in that this compound appears to exert a definite therapeutic effect in acute gouty arthritis. This effect was usually good and occasionally dramatic, but seemed to have no obvious advantage over colchicine. The dose used was $1 \mathrm{mg}$. for seven doses, and it is possible that higher doses would produce better results.

Worthy of emphasis was the lack of significant gastro-intestinal side-effects with colcemide. Similarly, the doses used caused no anaemia, thrombocytopenia, or leucopenia.

Since this work was begun a paper has appeared by Kuzell, Schaffarzick, and Naugler (1955), on the effect of intravenous colcemide in acute gout. 
TABLE

\begin{tabular}{|c|c|c|c|c|c|c|c|}
\hline $\begin{array}{l}\text { Patient } \\
\text { No. }\end{array}$ & Drug & $\begin{array}{l}\text { Dose and } \\
\text { Frequency }\end{array}$ & Route & $\begin{array}{l}\text { No. of } \\
\text { Doses }\end{array}$ & $\begin{array}{c}\text { Site of } \\
\text { Gouty Attack }\end{array}$ & Therapeutic Response & Side-Effects \\
\hline 1 & \multirow{3}{*}{ DOCA } & $\begin{array}{l}10 \mathrm{mg} . \\
12-\mathrm{hrly}\end{array}$ & Intramuscular & Seven & L. wrist & $\begin{array}{l}\text { In } 48 \text { min. pain better, ob- } \\
\text { jectively little change. } \\
\text { In } 96 \text { min. pain gone; } \\
\text { incomplete resolu- } \\
\text { tion objectively. }\end{array}$ & None \\
\hline 2 & & $\begin{array}{l}10 \text { mg. } \\
12-\text { hrly }\end{array}$ & Intramuscular & Six & $\begin{array}{l}\text { R. metatarso- } \\
\text { phalangeal }\end{array}$ & $\begin{array}{l}\text { Poor. Progression } \\
\text { during therapy }\end{array}$ & $\begin{array}{l}\text { Vomited once } \\
\text { Demerol } \\
\text { effect }\end{array}$ \\
\hline 3 & & $10 \mathrm{mg}$. & Intramuscular & One & L. ankle & No effect & None \\
\hline 4 & \multirow{4}{*}{$\begin{array}{l}\text { Colchicine } \\
\text { (intravenous } \\
\text { solution) }\end{array}$} & $1 \mathrm{mg}$. & Intra-articular & One & L. ankle & $\begin{array}{l}\text { Poor. Progression } \\
\text { after injection }\end{array}$ & None \\
\hline 5 & & $1 \mathrm{mg}$ & Intra-articular & One & L. knee & $\begin{array}{c}\text { Poor. Progression } \\
\text { after injection }\end{array}$ & None \\
\hline 6 & & $1 \mathrm{mg}$ & Intra-articular & One & R. knee & $\begin{array}{l}\text { Poor. Progression } \\
\text { after injection }\end{array}$ & None \\
\hline 7 & & $\begin{array}{l}1 \text { mg. } \\
\text { 24-hrly }\end{array}$ & Intra-articular & Two & L. knee & $\begin{array}{l}\text { Poor. Attack pro- } \\
\text { gressed, but later } \\
\text { responded to oral } \\
\text { colchicine }\end{array}$ & None \\
\hline \multirow[t]{2}{*}{8} & \multirow{5}{*}{ Benadryl } & & Intravenous & One & \multirow[t]{2}{*}{ R. knee } & \multirow{2}{*}{$\begin{array}{l}\text { No effect, then marked } \\
\text { improvement on } \\
\text { ACTH }\end{array}$} & None \\
\hline & & 4-hrly & Oral & Ten & & & \\
\hline \multirow[t]{2}{*}{9} & & 50 mg. & Intravenous & One & \multirow[t]{2}{*}{ R. ankle } & \multirow{2}{*}{$\begin{array}{l}\text { Poor. No response, } \\
\text { then usual response } \\
\text { with colchicine }\end{array}$} & \multirow[t]{2}{*}{ None } \\
\hline & & 4-hrly & Oral & Ten & & & \\
\hline 10 & & $50 \mathrm{mg}$. & Intravenous & One & R. ankle & $\begin{array}{l}\text { Poor. No response, } \\
\text { then usual response } \\
\text { with colchicine }\end{array}$ & None \\
\hline \multirow[t]{2}{*}{11} & \multirow{6}{*}{$\begin{array}{l}\text { Colcemide } \\
\text { (Demecolcine) }\end{array}$} & $2 \mathrm{mg}$. daily & Intravenous & Two & \multirow[t]{2}{*}{ R. elbow } & \multirow{2}{*}{$\begin{array}{l}\text { Improvement definite, } \\
\text { but not dramatic } \\
\text { In } 48 \text { hrs pain better } \\
\text { In } 72 \text { hrs tenderness } \\
\text { markedly improved }\end{array}$} & \multirow[t]{2}{*}{ None } \\
\hline & & $3 \mathrm{mg}$. daily & Oral & One & & & \\
\hline 12 & & $\begin{array}{l}1 \text { mg. } \\
\text { 2-hrly }\end{array}$ & Oral & Seven & $\begin{array}{l}\text { R. first metatarso- } \\
\text { phalangeal } \\
\text { R. first tarsal }\end{array}$ & $\begin{array}{l}\text { Marked relief in } 3 \mathrm{hrs} \\
\text { Rebound in } 48 \mathrm{hrs} \\
\text { Marked relief } 24 \mathrm{hrs} \\
\text { later }\end{array}$ & None \\
\hline 13 & & $\begin{array}{l}1 \mathrm{mg} . \\
\text { 2-hrly }\end{array}$ & Oral & Seven & $\begin{array}{l}\text { Both knees and } \\
\text { tarsals }\end{array}$ & $\begin{array}{l}\text { Excellent response in } \\
24 \mathrm{hrs}\end{array}$ & None \\
\hline 14 & & $\begin{array}{l}1 \text { mg. } \\
\text { 2-hrly }\end{array}$ & Oral & Seven & $\begin{array}{l}\text { R. ankle and } \\
\text { R. first metatarso- } \\
\text { phalangeal }\end{array}$ & $\begin{array}{l}\text { Slight improvement in } \\
24 \mathrm{hrs} \\
\text { Gradual resolution in } 7 \\
\text { days after colchicine }\end{array}$ & None \\
\hline 15 & & $\begin{array}{l}1 \text { mg. } \\
\text { 2-hrly }\end{array}$ & Oral & Seven & $\begin{array}{l}\text { L. metatarso- } \\
\text { phalangeal and } \\
\text { dorsum } \\
\text { L. foot and ankle } \\
\text { R. metatarsal and } \\
\text { knee }\end{array}$ & $\begin{array}{l}\text { Good improvement in } \\
48 \text { hrs with minimal } \\
\text { residual symptoms } \\
\text { Mild flare-up, improv- } \\
\text { ing in } 24 \mathrm{hrs}\end{array}$ & $\begin{array}{l}\text { Colchicine- } \\
\text { induced } \\
\text { diarrhoea } \\
\text { before col- } \\
\text { cemide }\end{array}$ \\
\hline
\end{tabular}

Using doses of 1 to $4 \mathrm{mg}$., usually in two successive daily intravenous injections, these workers found that fifteen out of twenty patients "enjoyed complete remission within 48 hours" of treatment. Our data supports these findings and suggests that oral as well as intravenous therapy is effective.

This drug, in the doses used, seems to be relatively safe and fairly effective in gouty arthritis, but we feel that a much larger experience with it is necessary before it can be recommended in gout.

\section{Summary}

(1) The results of therapeutic trials of four drugs in fifteen patients with acute gouty arthritis is discussed.

(2) DOCA (intramuscular) and Benadryl (intravenous) seemed to be ineffective in acute gouty arthritis.

(3) An intravenous solution of colchicine injected intra-articularly in $1 \mathrm{mg}$. doses was ineffective in terminating acute attacks of gouty arthritis. 
(4) Colcemide (Demecolcine), a new compound structurally related to colchicine, gave good results when used orally in 1-mg. doses as a therapeutic agent in gouty arthritis.

\section{REFERENCES}

Bock, H. E., and Gross, R. (1953). Klin. Wschr., 31, 816. Ferrannini, A., and De Pergola, E. (1950). Rif. Med., 64, 1241

Freyberg, R. H. (1955). "Meticorten and Meticortelone". The First International Conference on their Clinical and Metabolic Effects, May 31-June 1, 1955, New York. Published by the Schering Corporation.

Gutman, A. B., and Yü, T. F. (1950). Amer. J. Med., 9, 24

- , (1952). Ibid., 13, 744.

Harkavy, J. (1949). J. Amer. med. Ass., 139, 75.

Hartung, E. F. (1955). "Meticorten and Meticortelone." The First International Conference on their Clinical and Metabolic Effects, May 31-June 1, 1955, New York. Published by the Schering Corporation.

Hollander, J. L. (1953). Ann. intern. Med., 39, 735.

- (1955). "Meticorten and Meticortelone". The First International Conference.

Kuzell, W. C., Schaffarzick, R. W., and Naugler, W. E. (1955) Arch. intern. Med., 96, 153

Leonard, B. J., and Wilkinson, J. F. (1955). Brit. med. J., 1, 874

Levin, M. H. (1956). Unpublished data.

-, Rivo, J. B., and Bassett, S. H. (1953). Amer. J. Med., 15, 525.

Moeschlin, $\mathrm{S}$., Meyer, $\mathrm{H}$, and Lichtmen,

Steinbrocker, O., Neustadt, D. H., and Ehrlich, M. (1954). Med. clin. N. Amer., 38, 611 .

Stevenson, C. R., Zuckner, J., and Freyberg, R. H. (1952). Annals of the Rheumatic Diseases, 11, 112.

Violle, P. L. (1947). Presse méd., 55, 882.

Wolfson, W. Q., Hunt, H. D., Cohn, C., Robinson, W. D., and Duff, I. F. (1950). J. Mich. med. Soc., 49, 1058.
Essais thérapeutiques dans l'arthrite goutteuse aiguë

RÉSUMÉ

(1) Les résultats d'essais thérapeutiques de quatre produits sur quinze malades atteints d'arthrite goutteuse? aiguë sont discutés.

(2) DOCA (intramusculaire) et "Benadryl" (intra $\stackrel{\vec{F}}{?}$ veineux) semblèrent ineffectifs.

(3) Une solution intraveineuse de colchicine injectéeo intra-articulairement en doses de $1 \mathrm{mg}$. fut impuissante à arrêter les attaques aiguës.

(4) Colcémide (Demecolcine), un composé nouveau, $\mathbb{\mathscr { Q }}$ structuralement apparenté à la colchicine, administrén par voie buccale en doses de $1 \mathrm{mg}$., donna de bons résultats thérapeutiques.

\section{Ensayos terapéuticos en la artritis gotosa aguda}

\section{SUMARIO}

(1) Se discuten los resultados de ensayos terapéuticos de cuatro productos sobre quince enfermos afectos deartritis gotosa aguda.

(2) DOCA (intramuscular) y "Benadryl" (intra- $\omega$ venoso) no parecieron eficaces.

(3) No se consiguió terminar ataques agudos con una $\omega$ solución endovenosa de colchicina administrada intra-음 articularmente en dosis de $1 \mathrm{mg}$.

(4) Colcemide (Demecolcine), un compuesto nuevo, $\overrightarrow{C P}$ estructuralmente relacionado con la colchicina, adminis-D trado por vía oral en dosis de $1 \mathrm{mg}$., dió buenos resultados terapéuticos. 